\title{
Impact of pervious pavement in urban areas on catchment basin recovery
}

\section{Impacto da utilização de pavimentação permeável em áreas urbanas na recuperação de bacias hidrográficas}

\author{
Cristiano de Assumpção Santos ${ }^{1}$; Elisandro Pires Frigo ${ }^{2}$; Késia Damaris de \\ Azevedo Frigo ${ }^{1}$; Caroline Thaís Eckert ${ }^{1}$; Jonathan Dieter ${ }^{2}$; Helton José Alves ${ }^{2}$; \\ Luciene Kazue Tokura ${ }^{4 *}$; Reginaldo Ferreira Santos ${ }^{2}$
}

\begin{abstract}
Urbanization and disorderly occupation of urban areas have created several environmental problems, such as floods. Among the main causes of these problems is soil sealing associated with urban sprawl. Impervious surfaces provide less precipitation to recharge catchment basins by diverting water that should be restored in that region to other basins. This study compares two existing paving systems: concrete pavers with permeable joints and porous concrete pavers. Our objective was to learn which system better promotes the recovery of catchment basins and, consequently, mitigate problems caused by increasing surface runoff in urban areas. In order to reach the results, precipitations were simulated using lysimeters and a rainfall simulation infiltrometer at rainfall rates of 45,60 , and $90 \mathrm{~mm} \mathrm{~h}^{-1}$. The analyzed paving systems represented characteristics of public sidewalks. This experiment indicates that porous concrete pavers $(99.86 \%)$ and concrete pavers $(99.59 \%)$ present mean infiltration similar to that of grass cover $(100 \%)$ and thereby can promote water infiltration into soil and the recovery of catchment basins in urban areas.
\end{abstract}

Key words: Hydrology. Infiltration. Permeable concrete paving.

\section{Resumo}

\begin{abstract}
A urbanização e a ocupação desordenada das cidades criaram diversos problemas ambientais, como as inundações. Entre as causas destas ocorrências está, principalmente, a impermeabilização dos solos nas cidades, que ocorre pela interferência e necessidade do homem em utilizar mais espaço. As superfícies impermeabilizadas acabam proporcionando uma menor recarga das bacias hidrográficas, transferindo para outras bacias a quantidade de água que deveria ser reposta naquela região, desta forma prejudicam a recuperação das bacias onde ocorrem as percolações. O presente estudo faz um comparativo entre duas tecnologias existentes no mercado comercialmente conhecidos como "paver" e o "piso drenante", e aponta qual destas pode auxiliar na recuperação das bacias hidrográficas e, consequentemente, reduzir os problemas causados pelo aumento do escoamento superficial nas regiões urbanas. Para chegar ao resultado foram simuladas precipitações utilizando um infiltrômetro de aspersão em intensidades
\end{abstract}

\footnotetext{
${ }^{1}$ Discentes, Curso de Mestrado, Programa de Pós-Graduação em Engenharia de Energia na Agricultura, Universidade Estadual do Oeste do Paraná, UNIOESTE, Cascavel, PR, Brasil. E-mail: cristianoassump@hotmail.com; kesia.damaris@gmail.com; carolt. eckert@gmail.com

2 Prof. Dr., Programa de Pós-Graduação em Engenharia de Energia na Agricultura, UNIOESTE, Cascavel, PR, Brasil. E-mail: epfrigo@gmail.com; helquimica@gmail.com; reginaldo.santos@unioeste.br

3 Prof. Dr., Universidade Federal do Paraná, UFPR, Palotina, PR, Brasil. E-mail: jony.dieter@gmail.com;

${ }^{4}$ Pós-doutoranda do Programa de Pós-Graduação em Engenharia de Energia na Agricultura, Universidade Estadual do Oeste do Paraná, UNIOESTE, Cascavel, PR, Brasil. E-mail: lucienetokura@gmail.com

* Author for correspondence
} 
correspondentes a 45, $60 \mathrm{e} 90 \mathrm{~mm} \mathrm{~h}^{-1}$, e lisímetros onde as coberturas correspondem às características de passeios públicos utilizando as tecnologias a serem analisadas como cobertura de solo. Este experimento apontou que as peças de concreto permeável (piso drenante) $(99,86 \%)$ e as peças de concreto com juntas alargadas (paver) $(99,59 \%)$ apresenta valores médios da taxa de percolação (Figura 3D) assemelhada à cobertura de grama $(100 \%)$ e desta forma podem ser utilizadas como tecnologias para infiltração de água no solo auxiliando na recuperação das bacias hidrográficas das zonas urbanas.

Palavras-chave: Hidrologia. Infiltração. Piso de concreto permeável.

\section{Introduction}

Unplanned urbanization exposes soil to a variety of problems, such as soil sealing, which prevents rainwater infiltration, reduces groundwater recharge, and water availability during dry seasons.

Soil sealing is detrimental not only to cities but also to their surroundings because water that should infiltrate into the soil in a certain area runs off the surface somewhere downstream in the catchment due to reduced infiltration (GOMEZ-ULLATE et al., 2011; BEECHAM et al., 2012; MULLANEY; LUCKE, 2014; REIS; ILHA, 2014).

Rainwater retained on soil surface infiltrates the soil due to the earth's gravity and capillary action, or runs off (GARCEZ; ALVAREZ, 1988; RAIMBAULT et al., 2002). Infiltration is affected by geological characteristics of the soil, land relief, and obstacles offered to surface runoff (GARCEZ; ALVAREZ, 1988).

Infiltration capacity is directly related to porosity, particle size, and rock fissuration. A small surface layer in the order of one centimeter has great influence on infiltration capacity (PINTO et al., 1976).

According to Garcez and Alvarez (1988), surface runoff is a stage of the hydrological cycle. There is a direct link between surface runoff and precipitation, thus it is essential to analyze the correlation between these phenomena. The volume of surface runoff depends primarily on the volume of precipitated water, followed by soil infiltration, soil moisture, type of vegetation cover, surface permeability, and surface retention capacity (SCARATI MARTINS, 2006).
When it comes to urban drainage, it is understood as a series of measures to minimize the risk and reduce the damage caused by floods, as well as enable sustainable urban development (TUCCI, 2004).

Seeking ways to correct this imbalance, some solutions have been adopted; however, they are mostly based on rapid stormwater draining and discharging farther downstream. Other mitigation measures, such as permeable pavements, are also applied to promote water infiltration, slow surface runoff, or even regress to soil infiltration levels prior to urbanization.

Therefore, the objective of this research was to evaluate the effects of concrete pavers and porous concrete pavers on infiltration and surface runoff and to identify which type of soil cover of public sidewalks better promotes catchment basin recovery.

\section{Materials and Methods}

The boundaries of the municipality of Palotina are located in the Piquiri River watershed. The municipality occupies $647.3 \mathrm{~km}^{2}$, which constitutes $2.6 \%$ of the basin's area (SEMA, 2010) (Figure 1).

The experiment was conducted from August 2015 to January 2016 at the Federal University of Paraná - UFPR - Palotina Campus - western Paraná

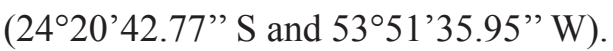

According to the Köppen and Geiger classification (2015), the climate in Palotina is classified as $\mathrm{Cfa}$, with warm temperatures, lack of dry seasons, and hot summers. The city of Palotina is located at an altitude of 305 meters. 
According to Embrapa (2006), the soil in the experimental area is classified as Typic Dystroferric Red Latosol with very clayey texture and a wide range of particle sizes, among which fine particles predominate fractionated as follows: $60 \%$ clay, $19 \%$ silt, and $21 \%$ sand.

Figure 1. Aerial view of the municipality of Palotina under the influence of the watershed of Piquiri River.

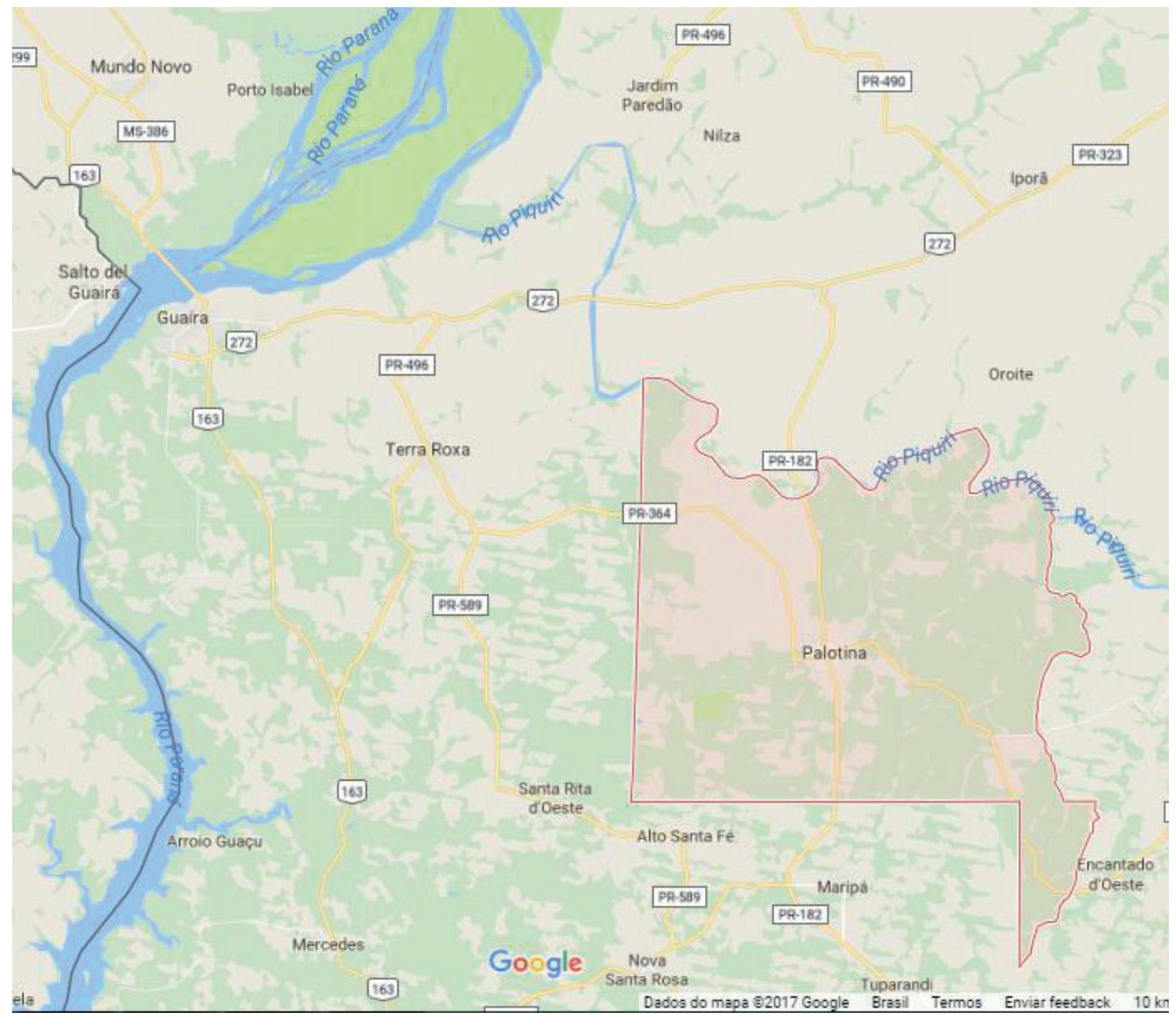

Fonte: Google Maps (2017).

\section{Experiment}

Four experimental plots were assembled. Each plot contained a different type of pavement covering the soil.

In order to approximate the experiment to natural conditions of public sidewalks, a construction method based on the Building Code of the City of Cascavel (CÓDIGO DE OBRAS DE CASCAVEL,
1996) was adopted. According to the Law number 2.582 , sidewalks must have a cross slope of $2 \%$ (two percent), and according to the NBR 9050 (ABNT, 2004) standard, sidewalks should have a cross slope of no more than $3 \%$, considering the dimension line of sidewalk's depth.

Each experimental unit, a lysimeter, was composed of a container $0.70 \mathrm{~m}$ wide, $1.00 \mathrm{~m}$ long, 
and $0.70 \mathrm{~m}$ deep. A gutter routing flow for surface runoff was placed at the front of the lysimeter and a tube at the bottom for subsurface runoff.
The spatial distribution of experimental plots can be observed in Figure 2. The experiment was divided into four plots to compare rainfall infiltration rates for different types of soil covers.

Figure 2. Distribution of plots on the experiment site.

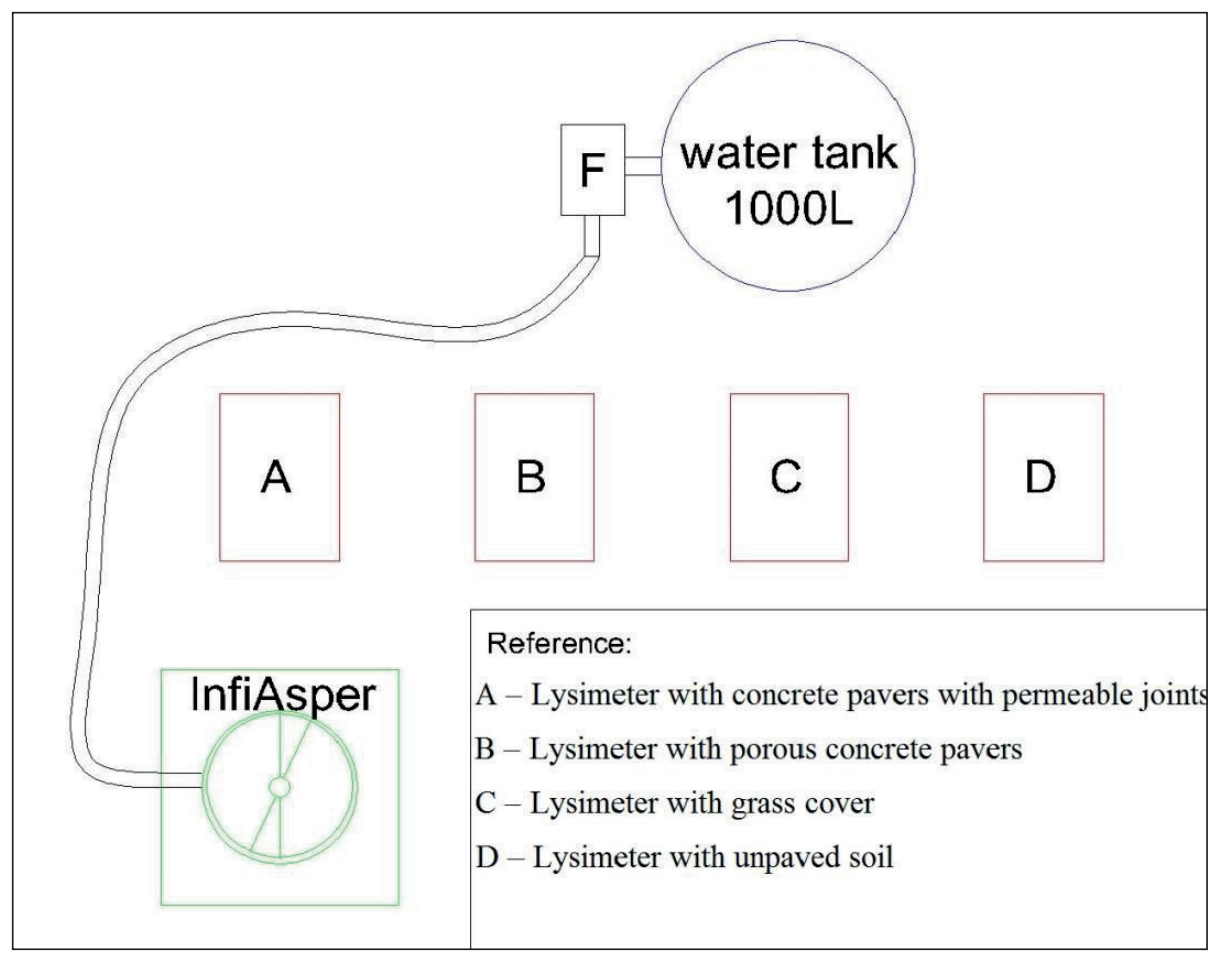

In lysimeter A, the ground cover represents public sidewalks paved with precast concrete pavers with permeable joints. It was assembled according to the NBR 16416 (ABNT, 2015) norm for a permeable paving system with full infiltration.

The native Dystroferric Red Latosol remained as the subgrade of the pavement. A permeable base of $5 \mathrm{~cm}$ was laid using crushed stone (particle size $12.5 \mathrm{~mm}$ ), as indicated by the NBR 16416 (ABNT, 2015) norm.

Then, a 3-cm bedding layer of sand (particle size $1.16 \mathrm{~mm}$ ) was laid also according to the norm previously mentioned. For the last layer, concrete pavers with permeable joints were used following the NBR 9781 (ABNT, 2013) norm, which determines that concrete pavers must have a minimum width of $97 \mathrm{~mm}$ and thickness of no less than $60 \mathrm{~mm}$.
Industry standard pavers were used in the experiment. The pavers were $100 \mathrm{~mm}$ wide and $200 \mathrm{~mm}$ long, fully meeting the requirements of the NBR 9781 (ABNT, 2013) norm, which determines specification and test methods for the manufacturing of paving concrete blocks. After installing the blocks, joints were filled up with sand, which had the same specification as for the bedding layer.

In lysimeter B, the soil cover represented public sidewalks paved with porous concrete pavers.

In this plot, the native Dystroferric Red Latosol also remained as the subgrade. The materials for the permeable base, bedding layer, and the thickness of layers followed the requirements of the NBR 16416 (ABNT, 2015) norm. The permeable base was laid using crushed stone with 12.5 -mm particle size and the bedding layer using sand with 1.16$\mathrm{mm}$ particle size. 
The last layer in lysimeter B was paved with porous concrete blocks of the NBR 9781 (ABNT, 2013) norm. Their overall dimensions were $200 \mathrm{~mm}$ long, $100 \mathrm{~mm}$ wide, and $60 \mathrm{~mm}$ thick.

Lysimeter C had grass-covered surface and lysimeter D represented unpaved public sidewalk.

Thus, it was possible to compare the reality of urban areas where homeowners do not make their sidewalks within the standards required by public agencies.

The behavior of runoff on plots with grass cover and unpaved soil was compared to pervious concrete paving, thereby seeking the most appropriate paving for public sidewalks that may help retain surface runoff and promote the recovery of catchment basins.

\section{Tensiometer}

A digital tensiometer (model MPM-160-B, ICT International, Australia) was used before the experimental tests to check moisture status of the soil in each plot.

Faria and Costa (1987) explain that the tensiometer is a device used to measure soil moisture and water tension. Readings of this device directly indicate water tension and water content in the soil.

A puncture of $50 \mathrm{~mm}$ in diameter was made on plots with concrete blocks through which soil moisture was checked.

\section{Rainfall intensity simulation}

The rainfall simulator used in this research project can generate various rates of rain over a plot of $0.70 \mathrm{~m}^{2}$ and operates at $32.7 \mathrm{kPa}$ pressure (InfiAsper/UFMS).

Simulations of various rainfall rates were performed until the soil basic infiltration velocity (i.e constant flow) was reached. The methodology employed to determine the timing was according to Panachuki et al. (2006).

According to soil and water loss studies carried out by Silva et al. (2005a, b) and Panachuki et al. (2006), a rainfall rate of $60 \mathrm{~mm} \mathrm{~h}^{-1}$ is considered capable of causing soil erosion. In this study, in addition to $60 \mathrm{~mm} \mathrm{~h}^{-1}$, a lower rate of $45 \mathrm{~mm} \mathrm{~h}^{-1}$ and a higher rate of $90 \mathrm{~mm} \mathrm{~h}^{-1}$ were chosen.

In rainfall simulations, three rates were used to determine the infiltration capacity of each type of cover in this project. In total, twelve rainfall simulations were conducted on four different types of covers.

Before each rainfall simulation, the equipment was calibrated (average of 5 replicates) to ensure that the rainfall rate would be close to the desirable (i.e. 45,60 , and $90 \mathrm{~mm} \mathrm{~h}^{-1}$ ) at $32 \mathrm{kPa}$ of service pressure.

The calibration of the equipment prior to each simulation consisted of five tests, each one lasting five minutes, during which the precipitated volume was collected in a metal tray of $0.70 \mathrm{~m}^{2}$, equivalent to the area of the experimental plot. Thus, the rate of precipitation applied by the simulator was identified.

After each simulation, the volume of precipitated water and the data from the calibration of the equipment were used in Equation 1, following the methodology developed by Alves Sobrinho (1997).

Calculations of rainfall rate with Equation 1:

$$
\operatorname{Ip}\left(m m h^{-1}\right)=\frac{V(L)}{A\left(m^{2}\right) * \frac{t(\min )}{60}}
$$

Where:

$I p=$ rainfall rate in $\mathrm{mm} \mathrm{h}^{-1}$;

$V=$ volume of water collected in metallic tray in liters;

$A=$ collection area in square meters;

$t=$ collection time in minutes. 


\section{Data collection}

After the calibration of the rainfall simulator, data were collected in each plot for each sample according to the methodology described by Alves Sobrinho (1997).

Before each rainfall simulation, soil moisture in every plot was checked. Pre-wetting was carried out to ensure an approximation of saturation in all treatments. After each pre-wetting, new soil moisture readings were done.

After these readings, procedures were carried out according to the methodology proposed by Alves Sobrinho (1997) and reapplied by Dieter (2009). The process consists of activating the rainfall simulator, which indicates the beginning of the test, and waiting for the beginning of surface runoff.

A sampling of the surface runoff was carried out every three minutes after the beginning of runoff, according to the methodology described by Dieter (2009). In total, 24 (twenty four) sample collections of surface runoff per experiment were carried out, for a total of 72 minutes of surface runoff in each plot. The rainfall simulator was turned off after the collection of the twenty-fourth sample, which was 72 minutes after the beginning of surface runoff. The end of surface runoff determined the end of the experiment in each plot.

After the end of each simulation, new readings of soil moisture in every lysimeter were conducted. To better understand the surface runoff data, each sample had its results separated by averaging the results from three runoff stages; each stage consisted of the sum of the volumes of 8 (eight) collections with a duration of 3 (three) minutes each. The data from the experiments have been tabulated to better understand the results obtained in this project. They are presented below.

\section{Results and Discussion}

The results obtained through sampling were divided according to rainfall rates. The first analyzed rate was $45 \mathrm{~mm} \mathrm{~h}^{-1}$, followed by $60 \mathrm{~mm} \mathrm{~h}^{-1}$ and 90 $\mathrm{mm} \mathrm{h}^{-1}$ for the four treatments.

Analyses followed a chronological order. They commenced with checking soil moisture in each lysimeter, followed by a simulated rainfall, when the data of surface runoff were collected, and another soil moisture verification. The last stage was an infiltration analysis of precipitated water.

The procedure started with soil moisture checking on experimental plots. Table 1 shows soil moisture data before and after pre-wetting.

As shown in Table 1, soil moisture before prewetting was under $30 \%$ in all treatments. Therefore, soil moisture was standardized to around $40 \%$ through pre-wetting to secure a better uniformity of data in the experiment.

Data collection started with turning the water pump on and waiting for the surface runoff to start. The data of surface runoff from the simulations have been tabulated in Table 2 below.

Table 2 shows that the volume of surface runoff for the same rainfall rate was directly related to the type of soil cover.

Figure 3 demonstrates that for the rainfall rate of $45 \mathrm{~mm} \mathrm{~h}^{-1}$, the lysimeter with unpaved soil provided the highest volume of runoff water, 1.63 liters.

Runoff volume in lysimeter B, treatment with porous concrete pavers, was about 30\% (thirty percent) of the runoff volume in lysimeter A, concrete pavers with permeable joints.

Figure $3 \mathrm{~A}$ also shows that lysimeter $\mathrm{C}$ with grass cover did not produce surface runoff for the rainfall simulation of $45 \mathrm{~mm} \mathrm{~h}^{-1}$. This lysimeter received precipitation during 87 minutes, yet no runoff was observed (Table 2). 
Table 1. Soil moisture levels for various rainfall rates.

\begin{tabular}{|c|c|c|c|c|}
\hline Types of soil cover & $\begin{array}{l}\text { Concrete pavers w/ } \\
\text { permeable joints } \\
\text { (A) }\end{array}$ & $\begin{array}{l}\text { Porous concrete } \\
\text { pavers (B) }\end{array}$ & $\begin{array}{l}\text { Grass } \\
\text { (C) }\end{array}$ & $\begin{array}{l}\text { Soil with no cover } \\
\text { (D) }\end{array}$ \\
\hline $45 \mathrm{~mm} \mathrm{~h}^{-1}$ & \multicolumn{4}{|c|}{ Moisture (\%) } \\
\hline Before pre-wetting & 31 & 24 & 29 & 16 \\
\hline After pre-wetting & 42 & 41 & 39 & 37 \\
\hline After the simulation & 46 & 45 & 49 & 48 \\
\hline $60 \mathrm{~mm} \mathrm{~h}^{-1}$ & \multicolumn{4}{|c|}{ Moisture (\%) } \\
\hline Before pre-wetting & 16 & 17 & 12 & 20 \\
\hline After pre-wetting & 39 & 43 & 39 & 38 \\
\hline After the simulation & 46 & 48 & 48 & 49 \\
\hline $90 \mathrm{~mm} \mathrm{~h}^{-1}$ & \multicolumn{4}{|c|}{ Moisture (\%) } \\
\hline Before pre-wetting & 16 & 17 & 12 & 20 \\
\hline After pre-wetting & 39 & 42 & 39 & 38 \\
\hline After the simulation & 46 & 48 & 45 & 49 \\
\hline
\end{tabular}

Table 2. Surface runoff for various rainfall rates.

\begin{tabular}{ccccc}
\hline Types of soil cover & $\begin{array}{c}\text { Concrete pavers } \\
\text { w/ permeable } \\
\text { joints (A) }\end{array}$ & $\begin{array}{c}\text { Porous concrete pav- } \\
\text { ers (B) }\end{array}$ & $\begin{array}{c}\text { Grass } \\
\text { (C) }\end{array}$ & Soil with no cover (D) \\
\hline & Desired rate of simulated rainfall & & $45 \mathrm{~mm} \mathrm{~h}^{-1}$ \\
\hline Total Runoff (L) & 0.18 & 0.062 & 0 & 1.63 \\
\hline Dotal Runoff (L) & Desired rate of simulated rainfall & 0 & $60 \mathrm{~mm} \mathrm{~h}^{-1}$ \\
\hline & 0.23 & 0.10 & & 21.91 \\
\hline Total Runoff (L) & Desired rate of simulated rainfall & 0 & $30 \mathrm{~mm} \mathrm{~h}^{-1}$ \\
\hline
\end{tabular}

Surface runoff on the plot with the unpaved surface in the simulation with $60 \mathrm{~mm} \mathrm{~h}^{-1}$ was higher than that with $45 \mathrm{~mm} \mathrm{~h}^{-1}$ because intense precipitation leads to the saturation point quicker, after which water runs off the surface instead of percolating into the soil. Figure 3B shows these data in a graph to facilitate understanding.

Further analysis of data in Table 2 shows that surface runoff in the rainfall simulation with 90 $\mathrm{mm} \mathrm{h}^{-1}$ produced a high volume of runoff from the unpaved soil.

Obtained data show that the grass cover remained free of surface runoff for all the simulated rainfall rates. Regarding the lysimeters with concrete pavers and porous concrete pavers, they demonstrated high absorption potential even at a precipitation of 90 $\mathrm{mm} \mathrm{h}^{-1}$ (Figure 3C). 
Figure 3. Surface runoff for rainfall rate of $45 \mathrm{~mm} \mathrm{~h}^{-1}(\mathrm{~A}), 60 \mathrm{~mm} \mathrm{~h}^{-1}(B), 90 \mathrm{~mm} \mathrm{~h}^{-1}$ (C) and infiltration percentage for evaluated precipitations (D).
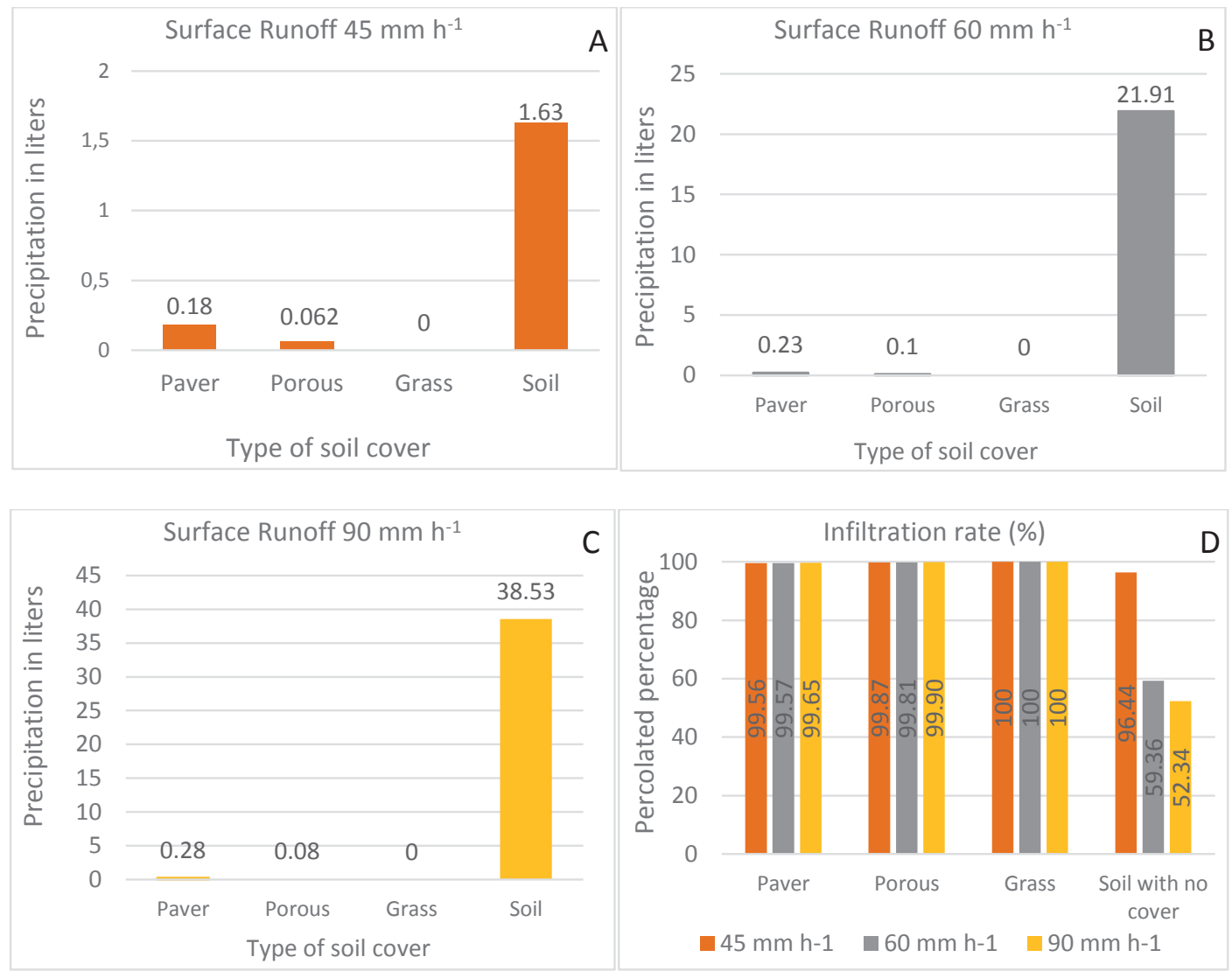

The above-mentioned Equation 1 was used to confirm the reliability of the experiment and to calculate the total volume of precipitation on the experimental area for each rate. The lysimeter with

concrete pavers accumulated about 40.95 liters of rainfall during 81 minutes on $0.70 \mathrm{~m}^{2}$.

Results of Equation 1 for rainfall rates of 45, 60, and $90 \mathrm{~mm} \mathrm{~h}^{-1}$ and their corresponding lysimeters are shown in Table 3.

Table 3. Simulation time for various rainfall rates.

Desired rate of simulated rainfall

\begin{tabular}{|c|c|c|c|c|}
\hline \multicolumn{5}{|c|}{ Desired rate of simulated rainfall } \\
\hline Types of soil cover & $\begin{array}{l}\text { Concrete pavers w/ } \\
\text { permeable joints (A) }\end{array}$ & $\begin{array}{l}\text { Porous concrete } \\
\text { pavers (B) }\end{array}$ & Grass $(\mathrm{C})$ & Soil with no cover (D) \\
\hline \multicolumn{4}{|c|}{ Desired rate of simulated rainfall } & $45 \mathrm{~mm} \mathrm{~h}^{-1}$ \\
\hline Total time (min) & 81 & 96 & 87 & 96 \\
\hline Precipitated water (L) & 40.95 & 49.35 & 45.68 & 45.68 \\
\hline \multicolumn{4}{|c|}{ Desired rate of simulated rainfall } & $60 \mathrm{~mm} \mathrm{~h}^{-1}$ \\
\hline Total time (min) & 78 & 78 & 87 & 81 \\
\hline Precipitated water $(\mathrm{L})$ & 52.50 & 53.20 & 60.90 & 53.90 \\
\hline \multicolumn{4}{|c|}{ Desired rate of simulated rainfall } & $90 \mathrm{~mm} \mathrm{~h}^{-1}$ \\
\hline Total time (min) & 78 & 78 & 87 & 81 \\
\hline Precipitated water $(\mathrm{L})$ & 78.75 & 79.80 & 91.35 & 80.35 \\
\hline
\end{tabular}


Surface runoff from the unpaved soil treatment was 1.63 liters for the rainfall rate of $45 \mathrm{~mm} \mathrm{~h}^{-1}$. Therefore, according to data in Table 3, it can be said that for this volume of rainfall, approximately $96.44 \%$ of the precipitated water tends to infiltrate into the soil.

In the same way as for the rainfall rate of $45 \mathrm{~mm}$ $\mathrm{h}^{-1}$, Equation 1 was used to estimate the total volume of precipitation in the area of the experiment. On average, 54.5 liters of precipitated water was captured at the rate of $60 \mathrm{~mm} \mathrm{~h}^{-1}$ on $0.70 \mathrm{~m}^{2}$ during 81 minutes.
Following the same procedure to calculate the volume of rainfall for 45 and $60 \mathrm{~mm} \mathrm{~h}^{-1}$ by replacing the values in Equation 1, an average volume of 82.56 liters of precipitated water was captured at 90 $\mathrm{mm} \mathrm{h}^{-1}$ during, on average, 81 minutes.

Using the collected data and the results of Equation 1, it was possible to present in Table 4 the rates of infiltration by the type of soil cover and volume of precipitated water. Thus, Table 4 helps better understand this research project.

Table 4. Soil Infiltration rates for evaluated rainfall rates.

\begin{tabular}{lcccc}
\hline Types of soil cover & $\begin{array}{c}\text { Concrete pavers w/ permeable } \\
\text { joints (A) }\end{array}$ & $\begin{array}{c}\text { Porous concrete } \\
\text { pavers (B) }\end{array}$ & $\begin{array}{c}\text { Grass } \\
\text { (C) }\end{array}$ & $\begin{array}{c}\text { Soil with no } \\
\text { cover (D) }\end{array}$ \\
\hline & Desired rate of simulated rainfall & & $45 \mathrm{~mm} \mathrm{~h}^{-1}$ \\
\hline Infiltration percentage & 99.56 & 99.87 & 100 & 96.44 \\
\hline & Desired rate of simulated rainfall & & $60 \mathrm{~mm} \mathrm{~h}^{-1}$ \\
\hline Infiltration percentage & 99.57 & 99.81 & 100 & 59.36 \\
\hline & Desired rate of simulated rainfall & 100 & $90 \mathrm{~mm} \mathrm{~h}^{-1}$ \\
\hline Infiltration percentage & 99.65 & 99.90 & & 52.34 \\
\hline
\end{tabular}

As shown in Table 4, lysimeter B with porous concrete pavers and lysimeter A with concrete pavers with permeable joints demonstrated infiltration rates very close to those in lysimeter $\mathrm{C}$ with grass cover. This happened at all analyzed rainfall rates during the experiment. The same data can be also observed in Figure 3A.

Rainfall rates of 60 and $90 \mathrm{~mm} \mathrm{~h}^{-1}$ produced the highest surface runoff on the unpaved soil in this experiment. In this lysimeter, surface runoff reached 21.91 liters for rainfall volume of 53.9 liters. This respectively represents $59.36 \%$ and $52.34 \%$ of infiltration into the soil as shown in Table 4 and Figure 3D.

Comparing all data for the rate of $60 \mathrm{~mm} \mathrm{~h}^{-1}$ with the rate of $45 \mathrm{~mm} \mathrm{~h}^{-1}$ presented in Table 4, no major changes in runoff profiles for grass lysimeters, concrete pavers with permeable joints, and porous concrete pavers were observed, with the exception of the lysimeter with unpaved soil, where the infiltration rate was drastically reduced.

In summary, precipitation volumes for the evaluated rates were very similar in lysimeters A and $\mathrm{B}$, with concrete block paving and porous concrete block paving. The averages were compared nonstatistically. Comparing these paving systems to the grass cover, their soil sealing effect was lower than $0.5 \%$ for all precipitation volumes.

The lysimeter with unpaved soil demonstrated infiltration of $96.44 \%$ at $45 \mathrm{~mm} \mathrm{~h}^{-1}$. However, when precipitation increased to $60 \mathrm{~mm} \mathrm{~h}^{-1}$ and $90 \mathrm{~mm} \mathrm{~h}^{-1}$, soil infiltration dropped to $52.34 \%$ in the case of the latter rate. This fact shows that the higher the rainfall rate is, the quicker the soil becomes saturated, that 
is the rainfall rate is higher than the soil infiltration rate, which inevitably leads to a high surface runoff.

Nowadays permeable pavements have various designs. The model chosen for this research followed the recommendations of NBR 16416 (ABNT, 2015) for porous concrete pavers. As presented in this work, this model of pavement has a very high infiltration rate, close to that of grass cover.

The NBR 16416 (ABNT, 2015) norm also presents another model of permeable paving analyzed in this project: concrete pavers with permeable joints. This model, if installed according to the guidance of the same norm, may also provide higher than $99 \%$ infiltration rate. It may be therefore used along with porous concrete pavers. Both systems allowed rainwater to return to the catchment basins through soil infiltration, thus promoting the recovery of catchment basins in urban developments and preventing damage to rural basins.

An interesting fact in this study was the low infiltration rate presented by the treatment with unpaved soil at high rainfall rates, being lower than the permeable concrete itself. Therefore, the use of unpaved soil is not recommended in regions with high rainfall intensity due to high surface runoff and the easiness of carrying residues that can obstruct urban stormwater drainage networks.

It was not the intention of this analysis to evaluate installation costs of each type of pavement, and thus validate or not the most cost-effective system. However, the obtained data show that, if installed as indicated by the regulatory norm, there are no substantial differences that warrant further investment in any other particular type of pavement, apart from aesthetic.

\section{Conclusions}

Treatments with porous concrete pavers and concrete pavers with permeable joints demonstrated infiltration rates similar to grass cover. Thereby, these pavements may promote water infiltration into the soil and the recovery of catchment basins in urban areas.

\section{References}

ALVES SOBRINHO, T. Desenvolvimento de um infiltrômetro de aspersão portátil. 1997. Tese (Doutorado em Engenharia Agrícola) - Universidade Federal de Viçosa, Viçosa, MG.

ASSOCIAÇÃO BRASILEIRA DE NORMAS TÉCNICAS - ABNT. NBR 9050:2004: Acessibilidade a edificações, mobiliário, espaços e equipamentos urbanos. Rio de Janeiro: ABNT, 2004.

NBR 9781:2013: peças de concreto para pavimentação: Especificação e métodos de ensaio. Rio de Janeiro: ABNT, 2013.

NBR 16416:2015: pavimentos permeáveis de concreto: Requisitos e procedimentos. Rio de Janeiro: ABNT, 2015.

BEECHAM, S.; PEZZANITI, D.; KANDASAMY, J. Stormwater treatment using permeable pavements. Water Management, London, v. 165, n. 3, p. 161-170, 2012.

CÓDIGO DE OBRAS DE CASCAVEL. Lei no 2582/96. Código de obras do município de Cascavel. Cascavel: PMC, 1996. Disponível em: <http://www.cascavel. pr.gov.br/secretarias/seplan/subpagina. php?id=930>. Acesso em: 8 jul. 2015.

DIETER, J. Poluição difusa por fósforo devido a aplicação de água residuária na suinocultura sob condições de chuva simulada. 2009. Dissertação (Mestrado em Engenharia Agrícola) - Universidade Estadual do Oeste do Paraná. Centro de Ciências Exatas e Tecnologia, Cascavel.

EMPRESA BRASILEIRA DE PESQUISA AGROPECUÁRIA - EMBRAPA. Sistema brasileiro de classificação de solo. 2. ed. Rio de Janeiro: EMBRAPASPI, 2006. 306 p.

FARIA, R. T. de; COSTA, A. C. S. da. Tensiômetro: construção, instalação e utilização: um aparelho simples para se determinar quando irrigar. Londrina: IAPAR, 1987. 24 p. (IAPAR, Circular, 56).

GARCEZ, L. N.; ALVAREZ, G. A. Hidrologia. 2. ed. São Paulo: Blucher, 1988. 291 p.

GOMEZ-ULLATE, E.; CASTILLO-LOPEZ, E.; CASTRO-FRESNO, D.; BAYON, J. R. Analysis and contrasto of different previous pavements for management of storm-water in a parking area in Northern Spain. Water Resources Management, Athens, v. 25, n. 6, p. 1525-1535, 2011. 
GOOGLE MAPS. Município de Palotina-PR (Rio Piquiri). Palotina: GM, 2017. Disponível em: <https:// www.google.com.br/maps/place/Palotina+-+PR/@24.2935963,-53.9550187,11z/data=! 3m1!4b1!4m5!3m4 !1s0x94f36de5b5882fb5:0x6f1c4038be1f7306!8m2!3d24.2808439!4d-53.8671868>. Acesso em: 29 set. 2017.

KÖPPEN, W.; GEIGER, R. Climate-data. org. Classificações climáticas. Oedheim: CDO, 2015. Disponível em: <http://pt.climate-data.org/ location/43679/>. Acesso em: 7 ago. 2015.

MULLANEY, J.; LUCKE, T. Practical review of pervious pavement designs. Clean Soil Air Water, Weinheim, Wiley-VCH, v. 42, n. 2, p. 111-124, 2014.

PANACHUKI, E.; ALVES SOBRINHO, T.; VITORINO, A. C. T.; CARVAlHO, D. F.; URCHEI, M. A. Parâmetros físicos do solo e erosão hídrica sob chuva simulada, em área de integração agricultura-pecuária. Revista Brasileira de Engenharia Agrícola e Ambiental, Campina Grande, v. 10, n. 2, p. 261-268, 2006.

PINTO, N. L. S.; HOLTZ, A. C. T.; MARTINS, J. A.; GOMIDE, F. L. S. Hidrologia básica. São Paulo. Ed. Blucher, 1976. 304 p.

RAIMBAULT, G.; ANDRIEU, H.; BERTHIER, E.; JOANNIS, C.; LEGRET, M. Infiltration des eaux pluviales à travers les surfaces urbaines: des revêtementes imperméables aux structures-réservoirs. Laboratoire Central des Ponts et Chaussées, 2002. n. 238, 50 p.
REIS, R. P. A.; ILHA, M. S. O. Performance evaluation of experimental pervious pavements with and without stone reservoir. Nagano: CIBW062 Symposium 2014, 2014. 12 p.

SCARATI MARTINS, J. R. Programa de capacitação em drenagem urbana e manejo sustentável de águas pluviais - gestão de drenagem urbana e inovações tecnológicas em micro drenagem. São Paulo: FCTH Fundação Centro Tecnológico de Hidráulica, 2006. v. 2, 9 p. (Apostila de Curso).

SECRETARIA DE ESTADO DO MEIO AMBIENTE E RECURSOS HÍDRICOS - SEMA. Bacias Hidrográficas do Paraná. Série Histórica. Curitiba: SEMA, 2010. 140 p.

SILVA, C. G.; ALVES SOBRINHO, T.; VITORINO, A. C. T.; CARVALHO, D. F. de. Atributos físicos, químicos e erosão entressulcos sob chuva simulada, em sistemas de plantio direto e convencional. Revista Brasileira de Engenharia Agrícola, Jaboticabal, v. 25, n. 1, p. 144-153, 2005a.

SILVA, F. F. P.; SCHAEFER, C. E. G. R.; AMORIM, R. S. S.; PAIVA, K. W. N. Efeito da cobertura nas perdas de solo em um Argissolo vermelho-amarelo utilizando simulador de chuva. Revista Brasileira de Engenharia Agrícola, Jaboticabal, v. 25, n. 1, p. 409-419, 2005 b.

TUCCI, C. E. M. Hidrologia. Ciência e aplicação. Porto Alegre: Ed. da Universidade - UFRGS/Ed. da Universidade de São Paulo - EDUSP/Associação Brasileira de Recursos Hídricos - ABRH, 2004. 469 p. 
